\title{
Antioxidant and Cytoprotective Properties of Three Egyptian Cyperus Species Using Cell-free and Cell-based Assays
}

\author{
Ahmed Hamed ${ }^{1}$, Maha Soltan*, ${ }^{*}$, Jeffrey Fry ${ }^{2}$, Faiza Hammouda ${ }^{1}$, and Adel Zaki ${ }^{1}$ \\ ${ }^{1}$ Chemistry of Medicinal Plants Department, National Research Centre (NRC), 12311, Dokki, Cairo, Egypt; ${ }^{2}$ School of \\ Biomedical Sciences, University of Nottingham Medical School, Queen's Medical Centre, Nottingham NG7 2UH, UK
}

\begin{abstract}
Three Egyptian Cyperus species viz. Cyperus esculentus, C. rotundus, and C. papyrus that belong to Cyperaceae were used as food and medicines since ancient times. This study aimed to investigate the direct and indirect antioxidant properties of the selected species in two chemical assays (FRAP and DPPH) and a cell-based bioassay in hepalc1c7 cells using $t$-butyl hydroperoxide (TBHP) as the inducer of cytotoxicity. Three different extracts were prepared from each Cyperus tuber. The results indicated that the $80 \% \mathrm{EtOH}$ extract of $C$. papyrus was the most potent with direct antioxidant activity in both DPPH $\left(\mathrm{EC}_{50}: 5.1 \mu \mathrm{g} / \mathrm{ml}\right)$ and FRAP $(\mathrm{FE}: 48.7 \mu \mathrm{g} / \mathrm{ml})$ assays and a significant full cytoprotection against TBHP at $100 \mu \mathrm{g} / \mathrm{ml}$.
\end{abstract}

Keywords: Antioxidant, Cytoprotection, Egyptian Cyperus, FRAP, DPPH, TBHP.

\section{INTRODUCTION}

The damage caused by free radicals and/or their resulting oxidative stress on the living cells has been extensively studied in recent years. Free radicals have been demonstrated to be the main initiator for many diseases such as cancer, Alzheimer's disease, Parkinson's disease, and rheumatoid arthritis $[1,2]$. For this reason, there has been intensive study of the antioxidant properties of plant extracts and isolated phytochemicals, with a view to identifying potentially useful antioxidant treatments.

Egypt is famous for the herbal medicine since ancient times [3]. It is still a confident way of remedy among Bedouins and folk communities. The verification of the medicinal uses of the traditional plants, of course will be great for their usefulness as a cheap and safe resource of natural medication.

Three Egyptian Cyperus L. (Cyperaceae) species viz. Cyperus esculentus L., C. rotundus L., and C. papyrus L. are claimed to cure and/or reduce many of the implicated symptoms that carried by diseases such as cancer [4]. An ayurvedic formulation containing $C$. rotundus was claimed as a remedy for some inflammatory disorders because of its significant inhibition against colitis and enterocolitis in rats. The same formulation was also found to be useful for ulcerative colitis in a clinical trial [5].

Our previous studies presented at conferences indicated that these species have hepatoprotective and antioxidant activities [6,7]. Other investigations demonstrated that the hydroalcoholic extract of $C$. Rotundus had antidiabetic activity in vivo [8] and in vitro [9] due to its antioxidant

*Address correspondence to this author at Chemistry of Medicinal Plants Department, National Research Centre (NRC), 12311, Dokki, Cairo,

Egypt; Tel: +201006077410; E-mail: mahasoltan@netscape.net properties. The same plant also showed to have antiviral [10], antibacterial, and antimutagenic activities [11]. In addition, the methanol extract of this herbal showed in vitro the potential as anti-inflammatory agent for inflammatory diseases mediated by overproduction of nitric oxide and superoxide [12].

The present study aimed to continue the investigation of the antioxidant properties of the selected species by employing an integrated two micro-scaled, cell-free antioxidant assays, namely the 2,2-diphenyl-1-picryl hydrazyl radical (DPPH) and the ferric reducing antioxidant power (FRAP), and a developed cell-based anti-"oxidative stress" assay in hepalc1c7 cells using tertiary-butyl hydroperoxide (TBHP) as inducer of cytotoxicity.

\section{MATERIALS AND METHODS}

\section{Chemicals and Reagents}

All chemicals and tissue culture reagents used in this work were purchased from Sigma-Aldrich Ltd. (Dorset, UK). Solvents used for the plant extraction were analytical grade.

\section{Plant Materials}

Dried tubers of C. esculentus were purchased from a legal Egyptian herbal market. Tubers of C. rotundus were provided from the National Research Centre Farm of Aromatic and Medicinal Plants. C. papyrus tubers were kindly provided from El-Karamos Village, El-Sharkia, Egypt. All species were identified by Prof. K. H. Batanouny, Department of Botany, Faculty of Science; Cairo University, Egypt. The voucher specimens were deposited at the herbarium of the Department of Botany, Faculty of Science; Cairo University, Egypt. The collected tubers from C. rotundus and C. papyrus were separately air dried in absence of direct sun light. 


\section{Preparation of Plant Extracts}

"The plant material was ground and extracted three times with a proper solvent to prepare three different extracts from each species. The solvents used for extraction were $80 \%$ ethanol $(80 \%$ EtOH $)$, a mixture of methylene chloride/methanol $\left(\mathrm{MeCl}_{2} / \mathrm{MeOH}, 1: 1\right)$ and hexane. The $80 \%$ $\mathrm{EtOH}$ extract was obtained after removal of ethanol under reduced pressure and then lyophilization. Other extracts were separately concentrated under vacuo at $40^{\circ} \mathrm{C}$."

\section{Cell-free Antioxidant Chemical Assays \\ DPPH Radical Scavenging Assay}

Plant extracts/compounds were prepared in DMSO as $10 \times$ stocks from each test concentration and briefly sonicated when necessary in an ultrasonic water bath. In a preliminary screen, plant extracts producing radical scavenging activities equal to or higher than $80 \%$ at $1000 \mu \mathrm{g} / \mathrm{ml}$ were taken for further testing to determine the $\mathrm{EC}_{50}$ (concentration of the extract/compound producing 50\% scavenging of the DPPH). Some known radical scavengers, quercetin (as dihydrate) and Trolox $^{\circledR}$, were tested in the assay as reference compounds. The method used in the present study was based on previously published methods $[13,14]$. The plant extract/compound stock solutions $(20 \mu 1 /$ well $)$ were pipetted in triplicate onto 96-well plates (flat-bottomed, Nunc). The assay was started with the addition of DPPH reagent $(0.004 \% \mathrm{wt} / \mathrm{v}$ in methanol, $180 \mu \mathrm{l} /$ well $)$. Appropriate blanks were prepared using the solvent only in addition to the same amount of DPPH reagent to get rid of any inherent solvent activity. The plate was immediately shaken in a Thermo ${ }^{\circledR}$ Multiscan Ascent plate reader for $30 \mathrm{sec}$ and incubated in the dark for $30 \mathrm{~min}$ at room temperature. The remaining DPPH was measured in a plate reader at $540 \mathrm{~nm}$. The percentage of antioxidant activity $(\% A A)$ was calculated using the following equation:

$\%$ Antioxidant activity DPPH $(\% A A)=100 \times \frac{[O D 540(\text { blank })-O D 540(\text { sample })]}{O D 540(\text { blank })}$

\section{Ferric Reducing Antioxidant Power (FRAP) Assay}

The FRAP values of plant extracts/compounds were determined based on previously published method [15] with some modifications. The FRAP reagent was prepared by mixing solution A [300 $\mathrm{mM}$ acetate buffer prepared by dissolving sodium citrate trihydrate $(3.1 \mathrm{~g} / \mathrm{l})$ and glacial acetic acid $(16 \mathrm{ml} / \mathrm{l})$ in distilled water], solution $B[31.2 \mathrm{mg}$ of 2,4,6-Tris(2-pyridyl)-s-triazine (TPTZ) dissolved in $10 \mathrm{ml}$ of $40 \mathrm{mM} \mathrm{HCl}$ ] and solution $\mathrm{C}$ [540 $\mathrm{mg}$ of ferric chloride hexahydrate dissolved in $100 \mathrm{ml}$ distilled water] in a volume ratio of 10:1:1, respectively. The FRAP reagent was warmed to $37{ }^{\circ} \mathrm{C}$ before being used. The plant extract concentrations $(10 \times, 20 \mu \mathrm{l})$ were added in triplicate onto wells of a 96-well plate (flat-bottomed, Nunc). The assay was started by adding $180 \mu \mathrm{l}$ of FRAP reagent to each well. Appropriate blanks were prepared from the solvent only and run simultaneously with the samples. The plate was immediately shaken in a Thermo ${ }^{\circledR}$ Multiscan Ascent plate reader for $30 \mathrm{sec}$ and the reaction was allowed to run for $10 \mathrm{~min}$ after which the plate was read on a plate reader $(595 \mathrm{~nm})$. A reference ferrous compound, ferrous sulphate $\left(\mathrm{FeSO}_{4}, 0-250 \mu \mathrm{M}\right.$ in distilled water), was run simultaneously and used to generate the calibration curve by linear regression.

\section{Cell-based Antioxidant Assay (Anti-TBHP)}

\section{Cell Culture}

Murine hepatoma cell line hepalc1c7 was obtained from the European Collection of Animal Cell Culture (UK) and maintained as monolayer culture grown in $175 \mathrm{~cm}^{2}$ flasks in a humidified atmosphere $\left(5 \% \mathrm{CO}_{2} / 95 \% \mathrm{O}_{2}\right)$ in $\alpha$-MEME supplemented by $10 \%$ foetal bovine serum (FBS), $2 \mathrm{mM}$ L-glutamine, $2 \mu \mathrm{g} / \mathrm{ml}$ Fungizone ${ }^{\text {тм }}$ and $50 \mu \mathrm{g} / \mathrm{ml}$ gentamicin.

\section{Bioassay Procedure}

TBHP was used as an oxidant in the cell-based assay in the present study. After routine sub-culture, hepalc1c7 cells were seeded onto 24 -well plates $\left(0.4 \times 10^{6}\right.$ cells/well). Confluent monolayers were pre-treated with either the plant extracts of Cyperus species (50 and $100 \mu \mathrm{g} / \mathrm{ml}$ ) or $0.5 \%$ DMSO (vehicle control) for $20 \mathrm{~h}$ after which the medium was discarded and monolayers washed briefly with Dulbecco's modified phosphate buffered saline (DPBS) (400 $\mu 1 /$ well). TBHP-containing culture medium was then added (2\% FBS and $200 \mu \mathrm{M}$ TBHP as final concentrations) and incubated for $5 \mathrm{~h}$. Following TBHP challenge, medium was discarded and the monolayers were washed once with DPBS as above and cell viability was assessed using neutral red uptake (NRU) assay, based essentially on the method of Borenfreund and Puerner [16]. Some reference protective compounds (quercetin, sulforaphane and $\beta-\mathrm{NF}$ ) were tested in parallel in the assay.

\section{Statistical Analysis}

The data were analysed using GraphPad Prism ${ }^{\circledR}$ software package (version 4). In terms of DPPH assay, the means of the values of the calculated \%AA obtained for plant extracts/compounds were plotted against their corresponding concentrations and the data were analyzed using non-linear regression (concentration-response) curve fit from which the $\mathrm{EC}_{50}$ values were obtained. For the FRAP assay, the standard curve of concentration-OD ( $595 \mathrm{~nm})$ for $\mathrm{FeSO}_{4}$ was fitted by linear regression. From the $\mathrm{FeSO}_{4}$ linear regression, the activities of plant extracts/compounds were represented as concentrations $(\mu \mathrm{g} / \mathrm{ml})$ equivalent to the OD $(595 \mathrm{~nm})$ of 100 $\mu \mathrm{M} \mathrm{FeSO}{ }_{4}$ (Ferrous equivalents, FE). All data presented were based on means of triplicate absorbance determinations. For the anti-TBHP assay, data were analyzed using One-way ANOVA followed by Dunnett's test to compare all groups including the control to the TBHP group. Data were considered significantly different when $\mathrm{P}<0.05$.

\section{RESULTS}

\section{DPPH Assay}

Table 1 displayed the DPPH assay results. The data were expressed as $\mathrm{EC}_{50}$ in $\mu \mathrm{g} / \mathrm{ml}$ as derived from the non-linear regression analysis of the concentration-response relation for each plant extract/compound. As representatives, the sigmoidal non-linear regression of the concentration- response of quercetin is demonstrated in Fig. (1). The produced scavenging activity for Cyperus extracts ranked in the following order: $80 \% \mathrm{EtOH}$ extract of C. papyrus $\left(\mathrm{EC}_{50}=5.1 \mu \mathrm{g} / \mathrm{ml}\right)>$ $80 \% \mathrm{EtOH}$ extract of $C$. rotundus $\left(\mathrm{EC}_{50}=44 \mu \mathrm{g} / \mathrm{ml}\right)>$ $\mathrm{MeCl}_{2} / \mathrm{MeOH}$ extract of C. papyrus $\left(\mathrm{EC}_{50}=44.8 \mu \mathrm{g} / \mathrm{ml}\right)>$ $\mathrm{MeCl}_{2} / \mathrm{MeOH}$ extract of $C$. rotundus $\left(\mathrm{EC}_{50}=222.2 \mu \mathrm{g} / \mathrm{ml}\right)$. 
Table 1. Results of the Antioxidant Cell Free Assays of Cyperus Plant Extracts and Reference Antioxidant Compounds

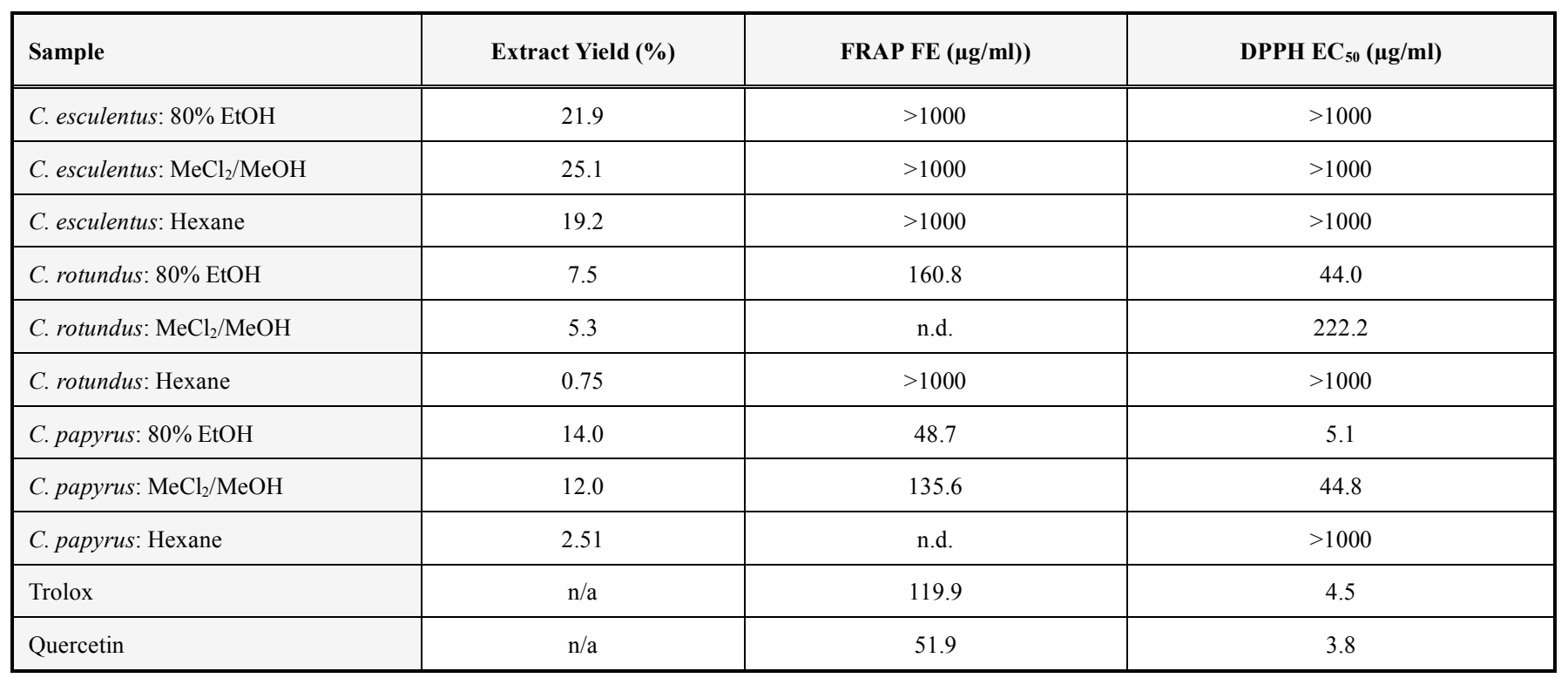

Note: FE: Ferrous equivalent (concentration equivalent to the $\mathrm{OD}(595 \mathrm{~nm})$ of $100 \mu \mathrm{M} \mathrm{FeSO}_{4}$ ); $\mathrm{EC}_{50}$; Concentration that produces $50 \%$ scavenging of the DPPH; n.d.: Not determined. n/a: not applicable.

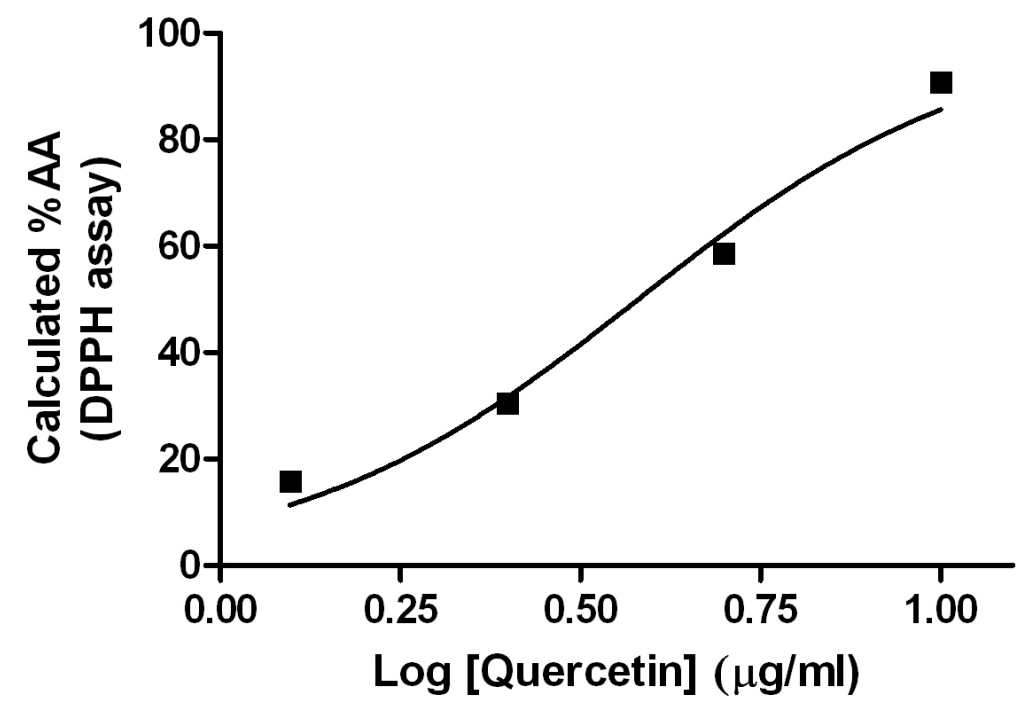

Fig. (1). Representative plots showing non-linear regression of the concentration-response effect of quercetin against calculated antioxidant activity $(\% \mathrm{AA})\left(\mathrm{R}^{2}=0.914\right)$. Data for the $\% \mathrm{AA}$ were calculated from the equation stated in the Methods section.

The three extracts from C. esculentus and the hexane extracts from both $C$. papyrus and $C$. rotundus showed weak or no antiradical activities $\left(\mathrm{EC}_{50}>1000 \mu \mathrm{g} / \mathrm{ml}\right)$.

\section{FRAP Assay}

In the FRAP assay, $\mathrm{FeSO}_{4}(0-250 \mu \mathrm{M})$ gave highly reproducible data. As demonstrated in Fig. (2), the linear regression analysis revealed a significant linear relationship ( $\mathrm{P}$ $<0.0001)$. From this analysis, the OD $(595 \mathrm{~nm})$ corresponding to $100 \mu \mathrm{M} \mathrm{FeSO}_{4}$ (FE) was found to be 1.20 as obtained with interpolation. Similarly, the linear regression analyses of plant extracts/compounds demonstrated significant linear relationships $(\mathrm{P}<0.01)$ of $\mathrm{Fe}^{3+}$ reduction with extract/compound concentration. The concentration of the extract/compound that gives an OD $(595 \mathrm{~nm})$ value of 1.20 was obtained by interpolation from its linear regression fit. This constructed the FRAP equivalent values (FE) expressed as $\mu \mathrm{g} / \mathrm{ml}$, as shown in Table 1. The plant extracts of Cyperus gave ferrous equivalent values at the order of $80 \% \mathrm{EtOH}$ extract of $C$. papyrus $(\mathrm{FE}=48.7 \mu \mathrm{g} / \mathrm{ml})>\mathrm{MeCl}_{2} / \mathrm{MeOH}$ extract of $C$. papyrus $(\mathrm{FE}=135.6 \mu \mathrm{g} / \mathrm{ml})>80 \% \mathrm{EtOH}$ extract of $C$. rotundus $(\mathrm{FE}=160.8 \mu \mathrm{g} / \mathrm{ml})$. 


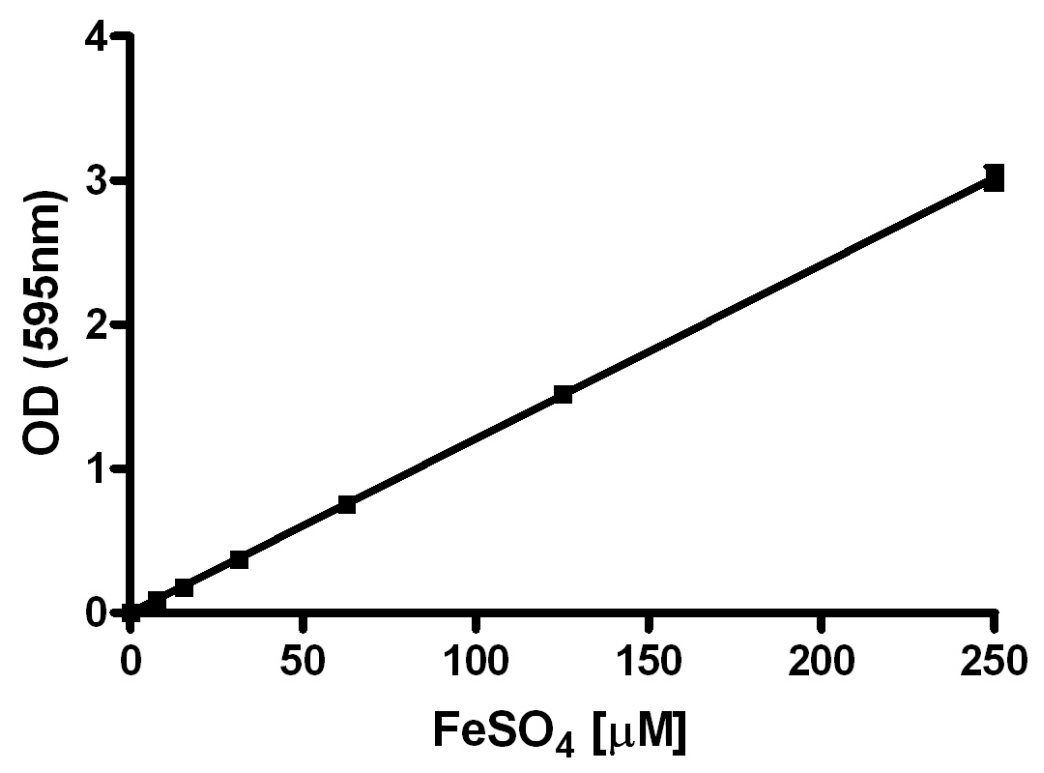

Fig. (2). Linear regression fit of FRAP standard curve for $\mathrm{FeSO}_{4}(\mathrm{P}<0.0001)$. Data shown are obtained from 6 triplicate absorbance determinations $(n=6)$.

Table 2. Integration of Anti-DPPH and Cell-Based Anti-TBHP Assays

\begin{tabular}{|c|c|c|c|c|}
\hline Treatment & \multicolumn{2}{|c|}{ Anti-DPPH } & \multicolumn{2}{|c|}{ Anti-TBHP } \\
\hline \multirow[t]{2}{*}{ C. papyrus: $80 \% \mathrm{EtOH}$} & \multirow{2}{*}{86} & \multirow{2}{*}{62.5} & $63.1 \pm 5.9$ & 50 \\
\hline & & & $98.3 \pm 2.0$ & 100 \\
\hline C. rotundus: $80 \% \mathrm{EtOH}$ & 90 & 125 & $70.1 \pm 8.0$ & 100 \\
\hline \multirow[t]{2}{*}{ C. papyrus: $\mathrm{MeCl}_{2} / \mathrm{MeOH}$} & \multirow{2}{*}{86} & \multirow{2}{*}{250} & $44.5 \pm 4.6$ & 50 \\
\hline & & & $53.5 \pm 7.0$ & 100 \\
\hline C. papyrus: Hexane & 10 & 1000 & $54.9 \pm 7.4$ & 50 \\
\hline$\beta$-naphthoflavone & 0 & n. d. & $72.8 \pm 3.4$ & $0.85^{\ddagger}$ \\
\hline Non-TBHP control & $\mathrm{n} / \mathrm{a}$ & $\mathrm{n} / \mathrm{a}$ & 100 & $\mathrm{n} / \mathrm{a}$ \\
\hline
\end{tabular}

Note: $\mathrm{EC}_{50}$ : concentration of the extract/compound producing $50 \%$ scavenging of the DPPH; Max.: Maximum; *: \% was calculated relative to DPPH control; $\uparrow: \%$ was calculated relative to the non-TBHP control. + : concentrations were selected based on a preliminary experiment (data not shown); n. d.: not determined due to the scavenging activity was lower than 50\%; n/a: not applicable. The TBHP control has showed only $32.6 \% \pm 2.6$ viability (i.e caused $67.4 \%$ loss of viability relative to the non-TBHP control.

\section{Cytoprotective Potential of Cyperus Extracts against TBHP Toxicity in Hepa1c1c7 Cells}

The most active extracts that showed scavenging activity against DPPH $\left(\mathrm{EC}_{50} \leq 44.8 \mu \mathrm{g} / \mathrm{ml}\right)$ were the $80 \% \mathrm{EtOH}$ extracts of both C. papyrus and C. rotundus followed by the
$\mathrm{MeCl}_{2} / \mathrm{MeOH}$ extract of C. papyrus. These extracts were tested in parallel with the active standard individual phytochemicals (quercetin, sulforaphane) in the development of the intracellular assay. The hexane extract of C. papyrus and $\beta$-naphthoflavone were also examined as they gave weak and no radical scavenging activity respectively, in order to test 


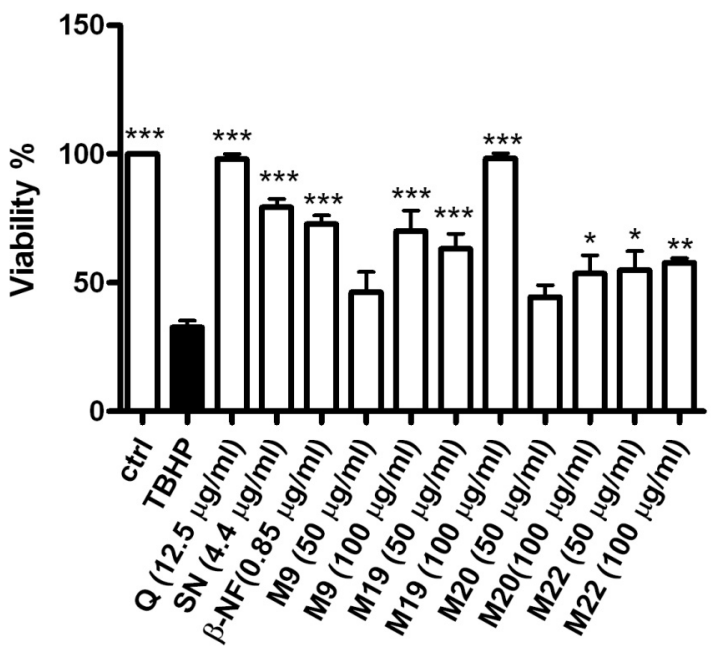

Fig. (3). Results of quercetin, sulforaphane, $\beta-\mathrm{NF}$ and some selected plant extracts in the anti-TBHP cytotoxicity assay. Ctrl: control; TBHP: tertiary-butyl hydroperoxide; Q: quercetin; SN: sulforaphane; $\beta$-NF: $\beta$-naphthoflavone; other ligands refer to the plant name, extract name and concentrations used in the assay (M9: $80 \%$ EtOH extract of C. rotundus; M19: 80\% EtOH extract of C. papyrus; $\mathrm{M} 20: \mathrm{MeCl}_{2} / \mathrm{MeOH}$ of $C$. papyrus; $\mathrm{M} 22$ : hexane extract of $C$. papyrus). Data shown are means \pm SEM ( $\mathrm{n}=5$ experiments). Data were analyzed using One-way ANOVA followed by Dunnett's test to compare all groups including the control to the TBHP group (colored in black). Asterisks $*, * *$ and $* * *$ refer to significantly different values where $\mathrm{P}<0.05, \mathrm{P}<0.01$, and $\mathrm{P}<0.001$, respectively.

the possibility of indirect anti-TBHP effect. Table 2 demonstrates the integration between the direct cell free and cell based assays where Fig. (3) represents the results of the antiTBHP bioassay. The TBHP used at $200 \mu \mathrm{M}$ has caused $67 \%$ loss of hepalc1c7 cell viability as compared to the nonTBHP treated control. Quercetin, used at final concentration of $12.5 \mu \mathrm{g} / \mathrm{ml}$ has showed a significant full cytoprotection against TBHP cytotoxicity. Sulforaphane $(4.4 \mu \mathrm{g} / \mathrm{ml})$ and $\beta$ NF $(0.85 \mu \mathrm{g} / \mathrm{ml})$ produced a significant 79 and $73 \%$ viability respectively.

The pretreatment of hepalc1c7 with $50 \mu \mathrm{g} / \mathrm{ml}$ of the $80 \%$ EtOH extract of C. papyrus tubers produced a $63 \%$ viability while the toxicity of TBHP was completely inhibited at the extract concentration of $100 \mu \mathrm{g} / \mathrm{ml}$. Lower anti-TBHP activities were produced by the $\mathrm{MeCl}_{2} / \mathrm{MeOH}$ extract of the same plant producing a significant $54 \%$ viability at the extract concentration of $100 \mu \mathrm{g} / \mathrm{ml}$. In addition, the pretreatment of hepa1c1c7 cells with the hexane extract of C. papyrus tubers (50 and $100 \mu \mathrm{g} / \mathrm{ml}$ ) produced a significant increase in the obtained cell viability recording about 55 and $58 \%$ viability, respectively. The $80 \% \mathrm{EtOH}$ extract of C. rotundus tubers produced $70 \%$ viability at the highest concentration tested $(100 \mu \mathrm{g} / \mathrm{ml})$.

\section{DISCUSSION AND CONCLUSION}

Nine extracts from three Egyptian Cyperus tubers were prepared and subjected to antioxidant investigation. The study included two chemical assays; FRAP and DPPH and one cell-based bioassay using hepalc1c7 cells where TBHP was the inducer of cytotoxicity. The results are part of a $\mathrm{Ph} . \mathrm{D}$. thesis [17] that suggested one chemical assay may be enough for representing the direct antioxidant effect where the DPPH assay was more recommended than the FRAP assay.

Three extracts namely; the $80 \% \mathrm{EtOH}$ extract of C. papyrus and C. rotundus and the $\mathrm{MeCl}_{2} / \mathrm{MeOH}$ extract of C. papyrus were the most active as radical scavengers $\left(\mathrm{EC}_{50}<\right.$ $44.8 \mu \mathrm{g} / \mathrm{ml}$ ) whereas the hexane extract of C. papyrus showed weak activity ( $10 \%$ scavenging at maximum concentration of $1000 \mu \mathrm{g} / \mathrm{ml}$ ). These extracts simultaneously with three phytochemical standards were used in the development of the cytoprotective bioassay to investigate the integration of the chemical and cell-based assays as indicated in Table $\mathbf{2}$. Interestingly, the $80 \% \mathrm{EtOH}$ extract of C. papyrus produced a significant nearly full cytoprotection against TBHP cytotoxicity which was similar to that produced by the reference antioxidant quercetin. Moreover, the recorded concentration values of the concerned extract (nearly full gain of control viability level at $100 \mu \mathrm{g} / \mathrm{ml} ; \mathrm{EC}_{50}=5.1 \mu \mathrm{g} / \mathrm{ml} ; \mathrm{FE}$ of 48.7 $\mu \mathrm{g} / \mathrm{ml}$ ) are comparable to quercetin as single compound (nearly full gain of control viability level at $12.5 \mu \mathrm{g} / \mathrm{ml}$; $\mathrm{EC}_{50}=3.8 \mu \mathrm{g} / \mathrm{ml} ; \mathrm{FE}$ of $51.9 \mu \mathrm{g} / \mathrm{ml}$ ) suggesting that the activity could be attributed to more than one active principle. The $\mathrm{MeCl}_{2} / \mathrm{MeOH}$ extract was less potent than the $80 \% \mathrm{EtOH}$ extract and the activity obtained at higher concentrations $\left(54 \%\right.$ viability at $100 \mu \mathrm{g} / \mathrm{ml} ; \mathrm{EC}_{50}=44.8 \mu \mathrm{g} / \mathrm{ml}$; FE of 135.6 $\mu \mathrm{g} / \mathrm{ml})$.

The chemical structures of the reference compounds sulforaphane and B-NF are devoid of directly acting antioxidant chemical groups, therefore their produced cytoprotective activities are mainly through induction of the cellular antioxidant capacity. Similarily, the hexane extract of C. papyrus produced a significant cytoprotection (58\% viability) and weak cell-free activity in the chemical antioxidant assays. Therefore, it might be suggested that hexane extract is acting indirectly to enhance the cellular antioxidant capacity of hepalc1c7 cells. It should be mentioned here that the use of integrated cell-free and cell-based set of assays are very important to conclude the potential of antioxidants.

Concerning C. rotundus, the $80 \% \mathrm{EtOH}$ extract was less potent than the corresponding extract of C. papyrus. It possessed the direct and indirect antioxidant activity as quercetin $\left(70 \%\right.$ viability at $100 \mu \mathrm{g} / \mathrm{ml} ; \quad \mathrm{EC}_{50}=44 \mu \mathrm{g} / \mathrm{ml}$; $\mathrm{FE}=160.8 \mu \mathrm{g} / \mathrm{ml}) . \mathrm{MeCl}_{2} / \mathrm{MeOH}$ of the same species showed $\mathrm{EC}_{50}$ at relatively higher concentration $(222.2 \mu \mathrm{g} / \mathrm{ml})$.

The increasing order of the activity shown by both $C$. papyrus and C. rotundus extracts are in the order of the increase in their polarity; $80 \% \mathrm{EtOH}>\mathrm{MeCl}_{2} / \mathrm{MeOH}>$ hexane, which emphasizes the presence of polar active substances. Previous reports showed the presence of polar classes of secondary metabolites in these two species such as polyphenols, alkaloids and essential oils which are known to possess antioxidant activities [18-23].

The cytoprotective activities shown by the studied extracts from Cyperus species are in agreement with some reports (ref. [24] by Soltan on isolated rat hepatocytes where these extracts showed a good protection against $\mathrm{CCl}_{4}$ toxicity model, the study performed by Natarajan and co-authors [25] who reported that $C$. rotundus has showed a significant scav- 
enging activity and the finding by Nagulendran and coauthors [26] who reported the direct and indirect antioxidant potency of $C$. rotundus).

The results obtained in the present study can provide, at least in part, an additional experimental justification for some reported folk medicinal uses of these plants. The traditional herbal reports mentioned that the selected species were edible [27, 28] and used to cure various chronic disorders such as cancer and to reduce many of the symptoms implicated in the free radical-related diseases.

\section{CONFLICT OF INTEREST}

Declared none.

\section{ACKNOWLEDGEMENTS}

The authors acknowledge the Egyptian Ministry of Higher Education and Scientific Research for financial support of this work. Many thanks are to Garry Clarke, SBMS, University of Nottingham for technical support.

\section{ABBREVIATIONS}

$\begin{array}{lll}\text { DPBS } & =\begin{array}{l}\text { Dulbecco's modified phosphate buffered } \\ \text { saline }\end{array} \\ \text { DPPH } & = & 2,2-\text { Diphenyl-1-picryl hydrazyl radical } \\ \text { FBS } & = & \text { Foetal bovine serum } \\ \text { FE } & = & \text { Ferrous equivalents } \\ \text { FRAP } & = & \text { Ferric reducing antioxidant power } \\ \text { NRU } & = & \text { Neutral red uptake } \\ \text { TBHP } & = & \text { Tertiary-butyl hydroperoxide } \\ \beta-N F & = & \beta \text {-naphthoflavone }\end{array}$

\section{REFERENCES}

[1] Aruoma, O. I. Free radicals, oxidative stress, and antioxidants in human health and disease. JAOCS, 1998, 75, 199-212.

[2] Pulido, R.; Bravo, L.; Saura-Calixto, F. Antioxidant activity of dietary polyphenols as determined by a modified ferric reducing/antioxidant power assay. J. Agric. Food Chem., 2000, 48 (8), 3396-402.

[3] Bryan, P. W. The Papyrus Ebers. Geoffrey Bles: London, 1930.

[4] Dr. Duke's Phytochemical and Ethnobotanical Databases. www.ars-grin.gov/duke (accessed October 15, 2011).

[5] Jagtap, A. G.; Shirke, S. S.; Phadke, A. S. Effect of polyherbal formulation on experimental models of inflammatory bowel diseases. J. Ethnopharmacol., 2004, 90 (2-3), 195-204.

[6] Soltan, M. M.; Hamed, A. R.; Zaki, A. K. In Biological properties overview on three cyperus species, The 2nd International Conference of The Arab Society for Medical Research (ASMR), Cairo, Egypt, 2008, p. 90.

[7] Soltan, M. M.; Zaki, A. K.; Hammouda, F. M. In Antioxidant activity of Cyperus papyrus, 50th Annual Congress of the Society-forMedicinal-Plant-Research, Barcelona, Spain, Sept. 8-12 2002, Barcelona, Spain, 2002, p. 130.
[8] Raut, N. A.; Gaikwad, N. J. Antidiabetic activity of hydroethanolic extract of Cyperus rotundus in alloxan induced diabetes in rats. Fitoterapia, 2006, 77 (7-8), 585-8.

[9] Ardestani, A.; Yazdanparast, R. Cyperus rotundus suppresses AGE formation and protein oxidation in a model of fructose-mediated protein glycoxidation. Int. J. Biol. Macromol., 2007, 41 (5), 572-8.

[10] Metra, S. K. Natural composition for curing hepatitis-B, methods for making the same and pharmaceutical formulations thereof. U.S. patent, 20060110479, May 25, 2006.

[11] Kilani, S., Abdelwahed, A., Chraief, I., Ben Ammar, R., Hayder, N., Hammami, M., Ghedira, K., Chekir-Ghedira, L. Chemical composition, antibacterial and antimutagenic activities of essential oil from (Tunisian) Cyperus rotundus. J. Essent. Oil., 2005, 17 (6), 695-700.

[12] Seo, W. G.; Pae, H. O.; Oh, G. S.; Chai, K. Y.; Kwon, T. O.; Yun, Y. G.; Kim, N. Y.; Chung, H. T. Inhibitory effects of methanol extract of Cyperus rotundus rhizomes on nitric oxide and superoxide productions by murine macrophage cell line, RAW 264.7 cells. $J$. Ethnopharmacol., 2001, 76 (1), 59-64.

[13] Braca, A.; De Tommasi, N.; Di Bari, L.; Pizza, C.; Politi, M.; Morelli, I. Antioxidant principles from Bauhinia tarapotensis. J. Nat. Prod., 2001, 64 (7), 892-5.

[14] Nara, K.; Miyoshi, T.; Honma, T.; Koga, H. Antioxidative activity of bound-form phenolics in potato peel. Biosci. Biotechnol. Biochem., 2006, 70 (6), 1489-91.

[15] Benzie, I. F.; Strain, J. J. The ferric reducing ability of plasma (FRAP) as a measure of "antioxidant power": the FRAP assay. Anal. Biochem., 1996, 239 (1), 70-6.

[16] Borenfreund, E.; Puerner, J. A. Toxicity determined in vitro by morphological alterations and neutral red absorption. Toxicol. Lett., 1985, 24 (2-3), 119-24.

[17] Hamed, A. Thesis, University of Nottingham, 2009.

[18] Nagababu, E.; Rifkind, J. M.; Boindala, S.; Nakka, L. Assessment of antioxidant activity of eugenol in vitro and in vivo. Methods Mol. Biol. 2010, 610, 165-80.

[19] Lee-Hilz, Y. Y.; Boerboom, A. M.; Westphal, A. H.; Berkel, W. J.; Aarts, J. M.; Rietjens, I. M. Pro-oxidant activity of flavonoids induces EpRE-mediated gene expression. Chem. Res. Toxicol., 2006, 19(11), 1499-505.

[20] Muzolf-Panek, M.; Gliszczynska-Swiglo, A.; de Haan, L.; Aarts, J. M.; Szymusiak, H.; Vervoort, J. M.; Tyrakowska, B.; Rietjens, I. M. Role of catechin quinones in the induction of EpRE-mediated gene expression. Chem. Res. Toxicol., 2008, 21(12), 2352-60.

[21] McClure, J. W. Phytochemical Phylogeny. Academic Press: London, 1970.

[22] Jaugaard, N. O.; Sckeri, M. M.; Schieferstein, R. H. The role of phenolics and abscisic acid in nutsedge tuber dormancy. Weed Sci. 1971, 19(1), 17-20.

[23] Bratt, K.; Sunnerheim, K.; Bryngelsson, S.; Fagerlund, A.; Engman, L.; Andersson, R. E.; Dimberg, L. H. Avenanthramides in oats (Avena sativa L.) and structure-antioxidant activity relationships. J. Agric. Food Chem. 2003, 51(3), 594-600.

[24] Soltan, M. M. Thesis. Cairo University, 2004.

[25] Natarajan, K. S.; Narasimhan, M.; Shanmugasundaram, K. R.; Shanmugasundaram, E. R. Antioxidant activity of a salt-spiceherbal mixture against free radical induction. J. Ethnopharmacol. 2006, 105(1-2), 76-83.

[26] Nagulendran, K.; Velavan, S.; Mahesh, R.; Hazeena Begum, V. In vitro antioxidant activity and total polyphenolic. Content of Cyperus rotundus rhizomes. Eur. J. Chem. 2007, 4, 440-449.

[27] University of Hawaii Campus Plants, UH Botany. http://www.botany.hawaii.edu/faculty/carr/page8.html (accessed Dec 14, 2011).

[28] Negbi, M. A sweetmeat plant, a perfume plant and their weedy relatives: a chapter in the history of Cyperus esculentus L. and $C$. rotundus L. Econ. Bot, 1992, 46, 64-71. 